DOI: $10.34220 /$ issn.2222-7962/2020.1/1

УДК 631.8

БИОСТИМУЛЯТОР ИЗ ОТХОДОВ КЕРАТИНСОДЕРЖАЩЕГО СЫРЬЯ

\author{
доктор сельскохозяйственных наук, профессор Л.В. Брындина \\ ФГБОУ ВО «Воронежский государственный лесотехнический университет имени Г.Ф. Морозова», \\ г. Воронеж, Российская Федерация
}

Деградация экосистем заставляет внедрять высокопродуктивные, экологичные биотехнологии в сельскохозяйственном производстве. В связи с этим возрастает интерес к органическому земледелию. Спрос на органические продукты опережает предложение. Это, в свою очередь, вызывает интерес к веществам, которые, с одной стороны, безопасны для окружающей среды, а с другой стороны - повышают урожайность и качество сельскохозяйственных культур. К таким веществам можно отнести биостимуляторы. Они стимулируют естественные процессы усвоения питательных веществ, повышают стресоустойчивость растений. В связи с этим особого внимания заслуживает кератинсодержащее сырье, которое по химическому составу представляет собой концентрат белка (90-95 \%). Но из-за низкой функциональности белка кератина этого сырья его применение ограничено. Ферментативный гидролиз кератина позволит получить биостимулятор для растений с высоким содержанием аминокислот. Целью исследования было разработать ферментативный способ гидролиза кератина с высоким содержанием аминокислот в конечном продукте. Ферментацию проводили протеиназой Str. chromogeness. g. 0832. Содержание растворимого белка, пептидов и аминокислот проводили фотоколориметрически. Определены температурные $\left(40{ }^{\circ} \mathrm{C}\right)$ и $\mathrm{pH}(8,0)$ - условия работы ферментного комплекса Str. chromogeness. g. 0832, которые позволили в дальнейшем провести гидролиз кератинсодержащего сырья с максимальным выходом конечных продуктов - аминокислот (99,57 г/100 г). Обработка семян кукурузы полученным раствором аминокислот позволила увеличить ростостимулурующую активность на 48 \%.

Ключевые слова: биостимуляторы, кератинсодержащее сырье, ферментативный гидролиз, органические отходы, аминокислоты

\title{
BIOSTIMULATOR MADE OF WASTE OF KERATIN-CONTAINING RAW MATERIALS
}

\author{
DSc (Argiculture), Professor L.V. Bryndina \\ FSBEI HE "Voronezh State University of Forestry and Technologies named after G.F. Morozov", \\ Voronezh, Russian Federation
}

\begin{abstract}
Ecosystem degradation forces us to introduce highly productive, environmentally friendly biotechnologies in agricultural production. In this regard, interest in organic farming is growing. Demand for organic products is ahead of supply. This, in its turn, causes interest in substances that, on the one hand, are safe for the environment, and on the other hand, increase yield and quality of crops. These substances include biostimulants. They stimulate the natural processes of assimilation of nutrients, increase stress resistance of plants. In this regard, keratin-containing raw materials deserve special attention, which, in terms of chemical composition, is a protein concentrate (90-95\%). But its use is limited due to the low functionality of the keratin protein of this raw material. Enzymatic keratin hydrolysis will provide a biostimulant for plants with a high content of amino acids. The aim of the study was to develop an enzymatic method for keratin hydrolysis with a high content of amino acids in the final product. Fermentation was carried out by Str. chromogeness. g. 0832 proteinase. The content of soluble protein, peptides and amino acids was carried out photocolorimetrically. Temperature $\left(400{ }^{\circ} \mathrm{C}\right)$ and $\mathrm{pH}(8.0)$ conditions of Str. chromogeness. $g .0832$ enzyme complex have been determined, which allowed further hydrolysis of keratin-containing raw materials with a maximum yield of final products - amino acids $(99.57 \mathrm{~g} / 100 \mathrm{~g})$. Treatment of corn seeds with the obtained amino acid solution enabled to increase growth-promoting activity by $48 \%$.
\end{abstract}

Keywords: biostimulants, keratin-containing raw materials, enzymatic hydrolysis, organic waste, amino acids 


\section{Природопользование}

\section{Введение}

В настоящее время критерием для использования любого производства, любой технологии является защита окружающей среды от загрязнения промышленными, сельскохозяйственными и другими отходами.

Перспективным направлением в последнее время является использование биостимуляторов для выращивания сельскохозяйственной продукции. Они способны значительно сократить время созревания продукции, повысить их качество за счет ускорения процессов поглощения питательных веществ. При этом являются экологически безопасными стимуляторами, так как имеют природное происхождение.

В связи с этим особого внимания заслуживает кератинсодержащее сырье (источник животного белка кератина). Птицеперерабатывающая отрасль активно развивается. Ежегодные объемы производства птицы увеличиваются в среднем на 12-15 \% [7]. Это ведет к накоплению значительных объемов побочного сырья, в том числе на перо, пух, подкрылок приходится 4,0$5,7 \%$ от общего количества отходов (15,3-28,3\%). Кератинсодержащее сырье по химическому составу представляет собой концентрат белка (90-95 \%) с высоким содержанием незаменимых аминокислот $[10,11,13]$. Но из-за низкой функциональности белков этого сырья (нерастворимость в воде, высокая механическая прочность, недоступность к действию пищеварительных ферментов и др.) применение этого белка ограничено. Это свойство кератина объясняется наличием большого числа поперечных дисульфидных связей между полипептидными цепями $[8,9]$. При разрыве этих связей кератин теряет свою устойчивость. Трудности заключаются в том, чтобы перевести этот белок в растворимое состояние, сохраняя при этом все аминокислоты данного белка. В этом случае наиболее приемлемы биотехнологические способы с использованием специфических ферментов, разрушающих компактную структуру кератиновой молекулы до усвояемых компонентов. Решение проблемы позволит получить биостимулятор для растений с высоким содержанием аминокислот.
Исходя из вышеизложенного, целью наших исследований было разработать биотехнологический способ переработки кератиновых отходов птицеперерабатывающей промышленности в ценный белковый продукт, который можно применять в качестве биостимулятора.

\section{Материалы и методы}

В качестве объекта исследования использовали перьевые отходы. Ферментным препаратом служила протеиназа Str. chromogeness. g. 0832 [2]. Все опыты проводили с измельченным пером при гидромодуле 1:20. Ферментативный гидролиз проводили в оптимальных для действия фермента условиях (концентрация препарата - 3 ед/г белка). Предварительную обработку кератина проводили тетраборатом натрия в концентрации 0,5 \% массовых, при давлении 0,20 МПа, продолжительность обработки - 2 ч. Степень гидролиза определяли как отношение аминного азота к общему. Общий азот определяли по методу Къельдаля, аминный азот определяли спектрофотометрически с использованием 2,4,6-тринитробензолсульфоновой кислоты. Аминокислотный анализ проводили на аминоанализаторе АAА 399М (Чехия). Протеолитическую активность определяли по ГОСТ 20264.2-88. Содержание растворимого белка, пептидов и аминокислот проводили фотоколориметрически. Предварительно каждую фракцию отделяли. 20 дм гидролизата обрабатывали трихлоруксусной кислотой для осаждения непрогидролизованых белков, полученный фильтрат использовали для определения пептидов и аминокислот. Пептиды определяли по биуретовой реакции, аминокислоты - по нингидриновой реакции. В таблицах и рисунках показаны данные, где каждое значение есть среднее из трех определений. При математической обработке результатов использовали критерий Стьюдента. Достоверными считали различия с уровнем значимости $q=5 \%$.

\section{Результаты и обсуждение}

Общеизвестно, что дисульфидные связи молекулы кератина выполняют стабилизирующую функцию. Реакционная способность этих связей значительно зависит от стерических факторов и электростатического влияния соседних полярных групп $[1,5]$. Для снижения устойчивости простран- 


\section{Природопользование}

ственной структуры белковой молекулы необходима предварительная подготовка белка к ферментации. Для этих целей использовали тетраборат натрия, который способствует увеличению выхода растворимых продуктов гидролиза при последующей ферментации. Деструкция кератина кислотами, щелочами, другими реагентами менее предпочтительна, так как ведет к разрушению отдельных аминокислот, превращению некоторых из них из биологически активной L-формы в неактивную D-форму. Растения усваивают $\alpha$-аминокислоты (протеиногенные) оптически активной L-конфигурации. Последние легко включаются в метаболические процессы клеток растений [3].

Известно, что на эффективность ферментации влияют стабильность фермента и условия протекания реакции [4]. Определение температурного и $\mathrm{pH}$ оптимума действия фермента позволит повысить скорость процесса гидролиза.

Оптимальной для действия фермента Streptomyzes chromogeness. g. 0832 оказалась температуpa $40{ }^{\circ} \mathrm{C}$. Протеолитическая активность в этих условия была максимальной и составила 233 ед/мг белка. При увеличении температуры до $50{ }^{\circ} \mathrm{C}$ сохраняется до $95 \%$ активности фермента. Дальнейшее повышение температуры до 60 и $70{ }^{\circ} \mathrm{C}$ сопровождается резким падением активности до 37 и 30 $\%$ соответственно (рис. 1). Происходит термическая инактивация фермента, сопровождаемая денатурацией белковой молекулы. Снижение температуры до $30{ }^{\circ} \mathrm{C}$ сопровождалось, так же как и в случае с температурой $50{ }^{\circ} \mathrm{C}$, незначительной потерей активности и составило $6 \%$ от исходного уровня. При $20{ }^{\circ} \mathrm{C}$ потеря протеолитической активности составила уже $44 \%$ от максимальной (рис. 1). Это явление объясняется изменением активного центра фермента из-за уменьшения плотности воды [4]. Следует отметить, что продолжительность воздействия температуры на ферментный комплекс также играет большую роль на скорость протекания ферментолиза.

Термостабильность фермента определяли при значении рН 8,0 (рис. 2) и температурах 30-60 ${ }^{\circ} \mathrm{C}$. Результаты эксперимента показали, что фермент стабилен на протяжении 4 часов при температурах 30 и $40{ }^{\circ} \mathrm{C}$. При температурах 50-
$60{ }^{\circ} \mathrm{C}$ остаточная активность уже через 2 ч инкубации снизилась на 45 и $60 \%$ соответсвенно. Результаты наших исследований также подтверждают общую прямую зависимость между скоростью инактивации фермента и степенью денатурации белка. Еще раз доказывая, что влияние температуры на скорость ферментативной реакцииподчиняется уравнению Аррениуса [4].

Исследование зависимости активности фермента от величины $\mathrm{pH}$ проводили при температуре $40{ }^{\circ} \mathrm{C}$ в диапазоне 5,0-11,0.

Из данных рис. 3 видно, чтопротеиназа из Str. chromogeness. g. 0832 активна в диапазоне pH 7,0-9,0. рН-оптимум соответствовал 8,0. Это подтверждает литературные данные, согласно которым кератинрасщепляющиепротеиназы имеют оптимум рН в щелочной области от 7,0 до 12,0 [12].

При сдвиге $\mathrm{pH}$ как в кислую, так и в щелочную сторону ферментативная активность резко падает. Возможно, конформационные изменения, происходящие в активном центре из-за изменения заряда молекулы фермента, приводят к потере его активности.

Кроме рН-оптимума, большое значение для протекания ферментативной реакции имеет $\mathrm{pH}$ стабильность. Это тот диапазон рН, при котором фермент сохраняет свою активность в течение определенного периода времени.

Исследование рН-стабильности (рис. 4), показало, что препарат стабилен в диапазоне $\mathrm{pH}$ $8,0-9,0$. После 12 ч инкубации при температуре $40{ }^{\circ} \mathrm{C}$ потеря активности составила при рН 9,0 $10 \%$, при $\mathrm{pH} 8,0-5 \%$. Инактивация фермента наблюдалась при более кислых (pH 6,0) и щелочных значениях рН (pH 10,0).

Определенные температурные и рН-условия работы ферментного комплекса Str. chromogeness. g. 0832 позволили в дальнейшем провести гидролиз кератинсодержащего сырья с максимальным выходом конечных продуктов - аминокислот.

Гидролиз белка кератина ферментным препаратом из Str. chromogeness. g. 0832 изучали в течение 6 часов. Результаты эксперимента, представленные на рис. 5, показали, что интенсивное расщепление кератинсодержащего сырья ферментным препаратом Str. chromogeness. 


\section{Природопользование}

g. 0832 происходит за первый час и достигает к 4-6 часам наибольшего значения 90-92 \%. Динамика накопления продуктов гидролиза, представленная в таблице, показывает, что ферментный комплекс Streptomyzes chromogeness. g. 0832 проявляет высокую специфичность к белку кератину. В основном конечными продуктами гидролиза кератина являются аминокислоты, и уже через 1 ч после ферментации их содержание составило $82,2 \%$.

Ферментативный гидролиз препаратом Streptomyzes chromogeness. g. 0832 позволил получить продукт с высокой биологической ценностью. Аминокислотный состав гидролизатапоказывает, что он содержит все аминокислоты (рис. 6). Особенно много в гидролизате было обнаружено глутаминовой кислоты и пролина. Общее количество аминокислот составило 99,57 г/100 г, сумма незаменимых аминокислот составила 42,66 г/100 г. Сумма серосодержащих аминокислот - 3,72 г/100 г.

Большинством ученых доказаны иммуномодулирующие, антистрессовые и регуляторные свойства аминокислот [6]. В связи с этим нами были проведены исследования по влиянию полученного комплекса аминокислот и пептидов из кератина пера на ростостимулирующую активность растений.
Семена кукурузы непосредственно перед высевом в грунт обрабатывали соответствующими растворами в концентрации 0,1 мл/л воды и выдерживали 0,5 часа. Контролем служили необработанные семена. По представленным на рис. 7 результатам видно, что обработка препаратами на начальных этапах вегетации положительно сказывается на дальнейших этапах роста. Сравнение ростостимулирующей активности предлагаемого биостимулятора с известным препаратом Рибав-Экстра показало, что эффективность полученного препарата выше существующего аналога на 23 \% и на 48 \% в сравнении с контролем.

\section{Заключение}

Проведенные исследования показали эффективность переработки кератиновых отходов птицеперерабатывающей промышленности в высокоэффективный биостимулятор роста растений. Высокое содержание свободных аминокислот в конечном продукте влияет на повышение урожайности сельскохозяйственных культур. Экологическая безопасность этих препаратов позволит использовать их при выращивании экологически чистых растений.

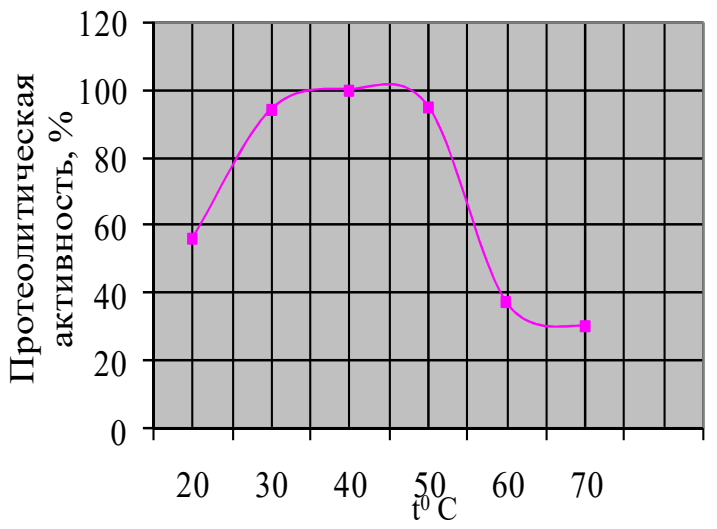

Рис. 1. Зависимость протеолитической активности Str. chromogeness. g. 0832 от температуры (собственные экспериментальные данные и вычисления автора) 


\section{Природопользование}

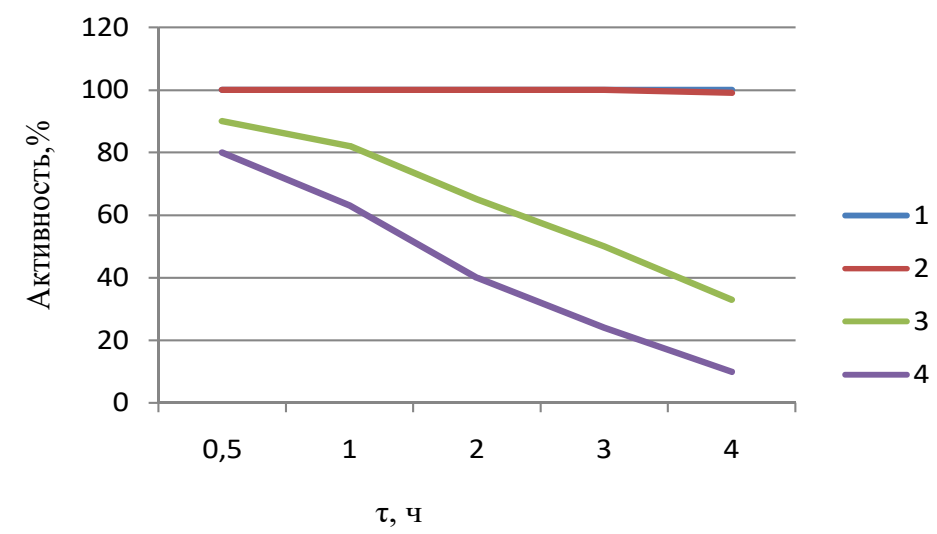

Рис. 2. Влияние температуры на стабильность фермента Str. chromogeness. g. 0832:

$$
1-30{ }^{\circ} \mathrm{C}, 2-40{ }^{\circ} \mathrm{C}, 3-50{ }^{\circ} \mathrm{C}, 4-60{ }^{\circ} \mathrm{C}
$$

(собственные экспериментальные данные и вычисления автора)

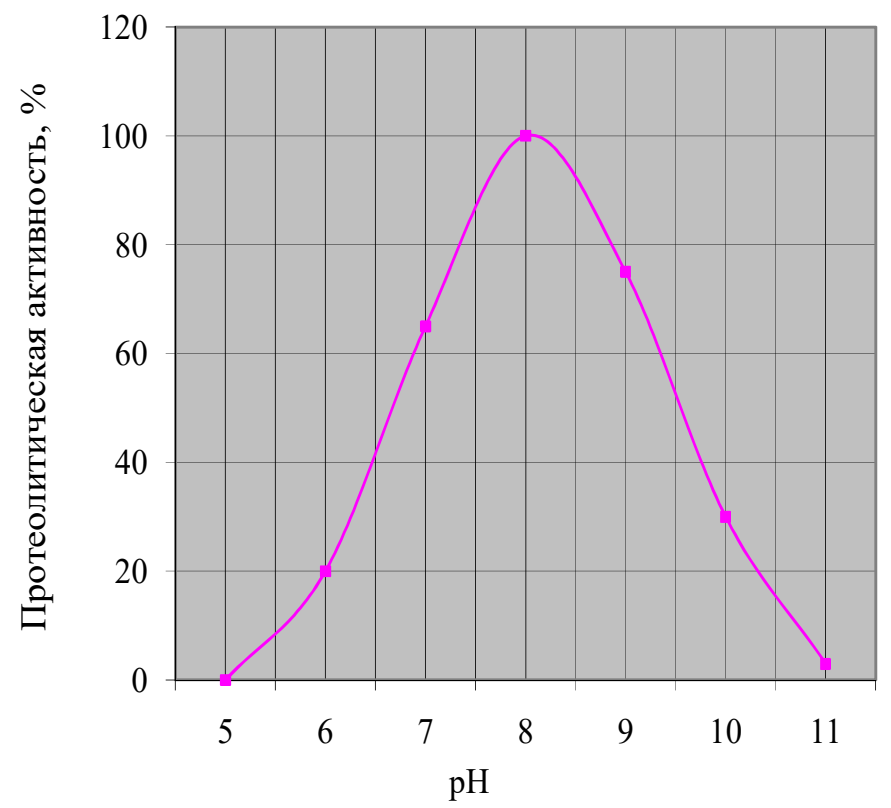

Рис. 3. Зависимость протеолитической активности Str. chromogeness. g. 0832 от pH (собственные экспериментальные данные и вычисления автора) 


\section{Природопользование}

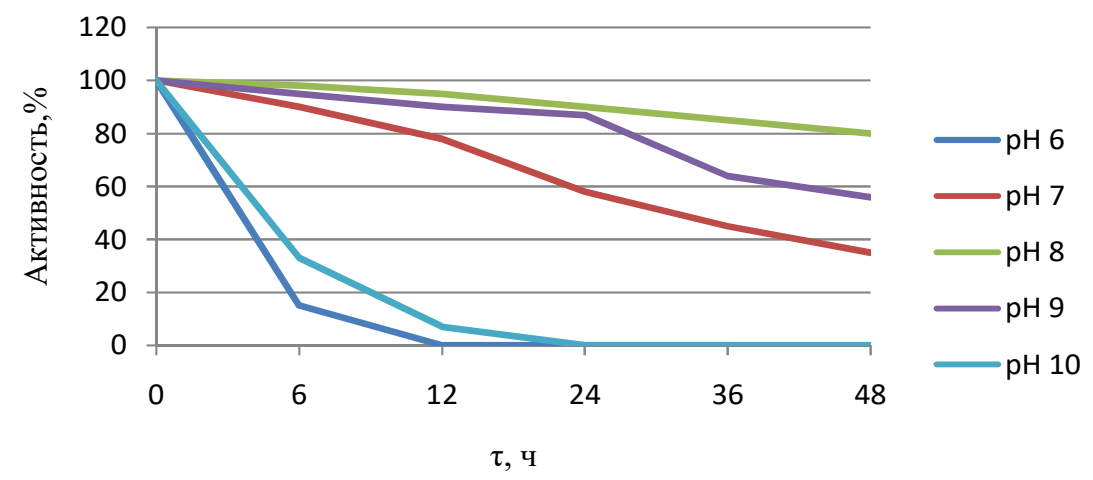

Рис. 4. Влияние величины рН на стабильность фермента Str. chromogeness. g. 0832 (собственные экспериментальные данные и вычисления автора)

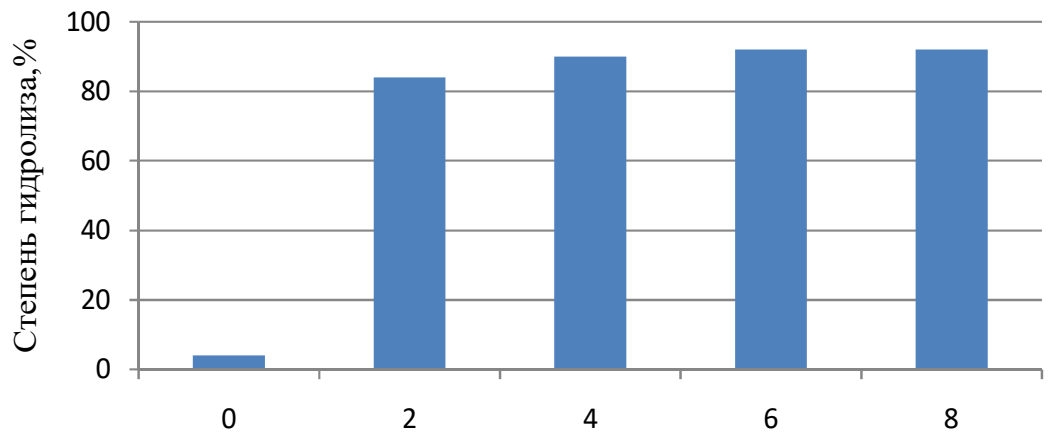

Продолжительность гидролиза, ч

Рис. 5. Влияние продолжительности ферментативного гидролиза на степень гидролиза пера (собственные экспериментальные данные и вычисления автора)

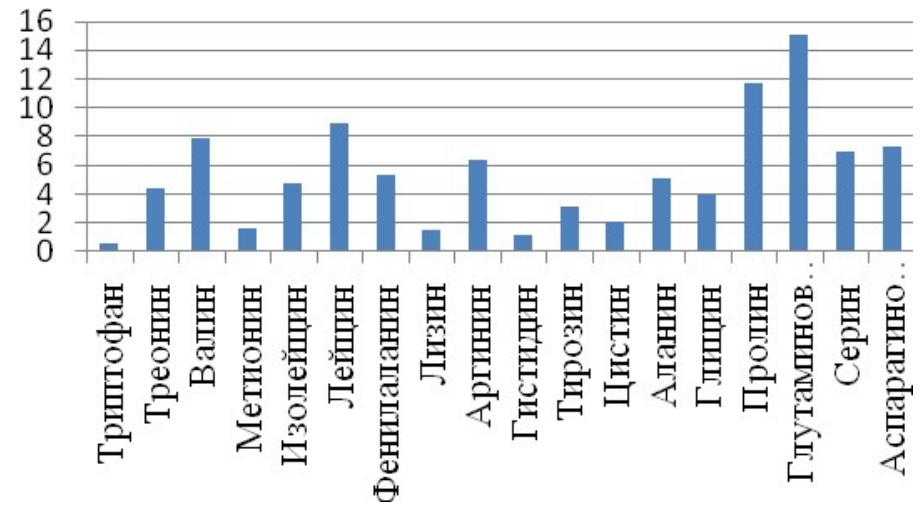

Рис. 6. Аминокислотный состав гидролизата из кератина пера (собственные экспериментальные данные и вычисления автора) 


\section{Природопользование}

Таблица

Динамика накопления продуктов ферментативного гидролиза белка кератина

\begin{tabular}{|c|c|c|c|}
\hline \multicolumn{1}{|c|}{ Показатель } & \multicolumn{3}{|c|}{ Содержание, \% в 100 дм $^{3}$} \\
\hline $\begin{array}{l}\text { Продолжительность } \\
\text { гидролиза, ч }\end{array}$ & растворимый белок & пептиды & аминокислоты \\
\hline 0 & 4,2 & 1,4 & 0 \\
\hline 1 & 4,5 & 1,5 & 82,2 \\
\hline 2 & 4,7 & 1,8 & 87,1 \\
\hline 3 & 4,7 & 2,2 & 88,4 \\
\hline 4 & 6,1 & 2,4 & 88,6 \\
\hline 5 & 5,1 & 3,2 & 88,9 \\
\hline 6 & 5,1 & 3,6 & 89,0 \\
\hline
\end{tabular}

(собственные экспериментальные данные и вычисления автора)

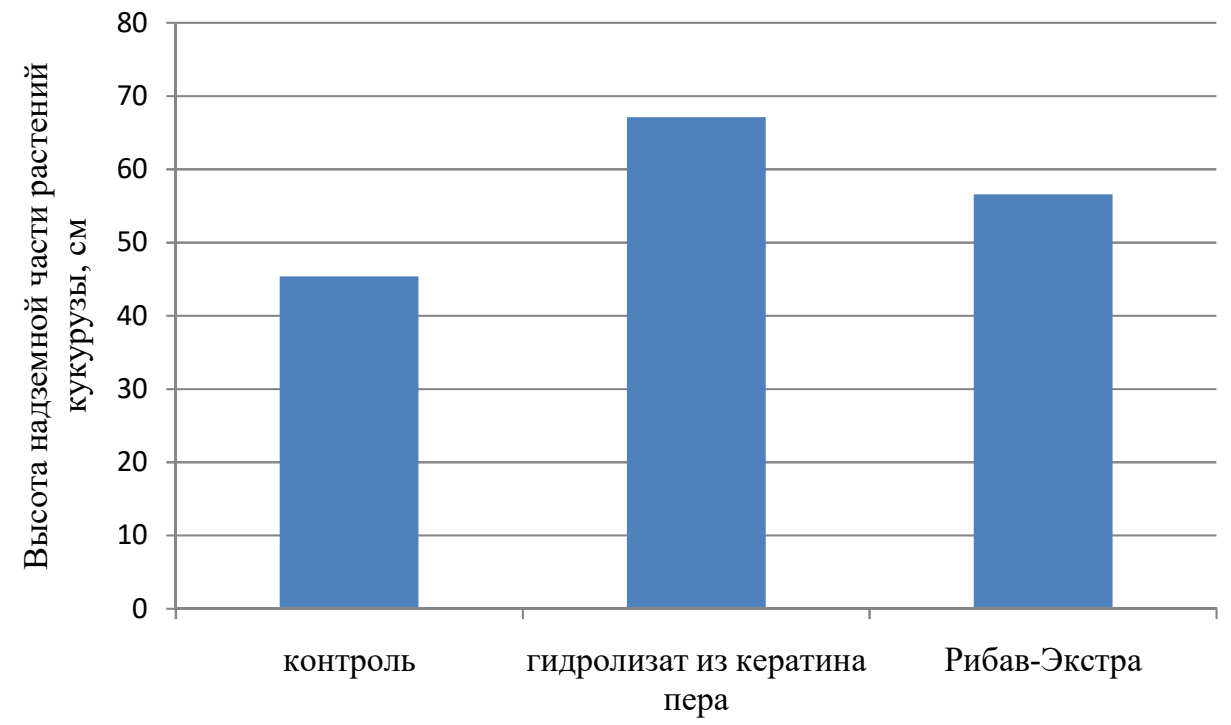

Рис. 7. Стимулирование роста растений замачиванием семян в растворе биостимулятора из кератина пера (собственные экспериментальные данные и вычисления автора) 


\section{Природопользование}

\section{Библиографический список}

1. Бортников, С. В. Получение растворимой модификации кератина из белоксодержащих отходов животноводства / С. В. Бортников, Г. А. Горенкова // Успехи современного естествознания. - 2018. - № 4. C. 17-22. - URL: http://natural-sciences.ru/ru/article/view?id=36719 (дата обращения: 26.01.2020).

2. Брындина, Л. В. Изучение физико-химических свойств ферментных систем флокулянта Streptomyces chromogeness. g. 0832 / Л. В. Брындина // Экология и промышленность России. - 2012. - № 11. - С. 48-50.

3. Кретович, Л. В. Биохимия растений / Л. В. Кретович. - Москва : Высшая школа, 1986. - 503 с.

4. Нельсон, Д. Н. Основы биохимии Ленинджера : в 3 т. Т. 1 : Основы биохимии, строение и катализ / Д. Нельсон, М. Кокс ; пер. с англ. -3-е изд., испр. - Москва : Лаборатория знаний, 2017. - 694 с. : ил. - (Лучший зарубежный учебник). - ISBN 978-5-00101-014-2 (T. 1); ISBN 978-5-00101-013-5B. - URL: http://binompress.ru/books_1/biology/lenindger_1.pdf (дата обращения 25.01.2020).

5. Смирнова, И. Р. Функциональный кератин пера как источник белка и незаменимых аминокислот в кормлении сельскохозяйственной птицы / И. Р. Смирнова, Л. П. Сатюкова, М. И. Шопинская // Проблемы ветеринарной санитарии, гигиены и экологии. - 2016.- № 3. - С. 78-83.

6. Усвоение растениями аминокислот // Агрохимия. Информационный некоммерческий ресурс. - URL: http://agrohimija.ru/mikroorganizmy-pochvy/1821-usvoenie-rasteniyami-aminokislot.html (дата обращения: 26.01.2020).

7. Эффективное использование вторичного сырья, получаемого при переработке птицы / В. Г. Волик, Д. Ю. Исмаилова, О. Н. Ерохина [и др.] // Птица и птицепродукты. - 2011. - № 3. - C. 16-19. - URL: http://www.vniipp.ru/images/statya/0311/s16.pdf (дата обращения 29.01.2020).

8. Casarin, F. Use of Poultry Byproduct for Production of Keratinolytic Enzymes / F. Casarin, F. CladeraOlivera, A. Brandelli // Food and Bioprocess Technology. - 2008. - Vol. 1. - P. 301-305. - DOI: https://doi.org/10.1007/s11947-008-0091-9.

9. Gupta, R. Microbial keratinases and their prospective applications: an overview / R. Gupta, P. Ramnani // Applied Microbiology and Biotechnology. - 2006. - V. 170. - P. 21-33. - DOI: https://doi.org/10.1007/s00253-0050239-8.

10. Kirfel, J. Keratins: a structural scaffold with emerging functions / J. Kirfel, T. M. Magin, J. Reichelt // Cellular and Molecular Life Sciences CMLS. - 2003. - Vol. 60. - P. 56-71. - DOI: https://doi.org/10.1007/s000180300004.

11. Körner, A. MALDI MS in Analysis of Keratin Fibre Proteins / A. Körner // Applications of Mass Spectrometryin Life Safety. - 2008. - P. 205-212. - DOI: https://doi.org/10.1007/978-1-4020-8811-7_14.

12. Characterization of a new keratinolytic Trichoderma atroviride strain F6 that completely degrades native chicken feather / L. Cao, H. Tan, Y. Liu, X. Xue, S. Zhou // Letters in Applied Microbiology. - 2008. -Vol. 46. P. 389-394. - DOI: https://doi.org/10.1111/j.1472-765X.2008.02327.x.

13. Enzymatic hydrolysis of keratin-containing stock for obtaining protein hydrolysates / N. L. Eremeev, I. V. Nikolaev, I. D. Keruchen'ko [et al.] // Applied Biochemistry and Microbiology. - 2009. - Vol. 45. - No. 6. P. 717-724. - DOI: https://doi.org/10.1134/S0003683809060131.

\section{References}

1. Bortnikov S. V., Gorenkova G. A. (2018) Poluchenie rastvorimoj modifikacii keratina iz beloksoderzhashchih othodov zhivotnovodstva. Uspekhi sovremennogo estestvoznaniya. № $4 . \quad$ P. 17-22. URL: http://naturalsciences.ru/ru/article/view?id=36719 (date of access: 26.01.2020) (in Russian).

2. Bryndina L. V. (2012) Izuchenie fiziko-himicheskih svojstv fermentnyh system flokulyanta Streptomyces chromogeness.g. 0832. Ekologiya i promyshlennost' Rossii. № 11. P. 48-50 (in Russian).

3. Kretovich L. V. Biohimiya rastenij. Moscow: Vysshaya shkola, 1986. 503 p. (in Russian). 
4. Nel'son D. N., Koks M. Osnovy biohimii Lenindzhera: 3 vol. Vol. 1: Osnovy biohimii, stroenie i kataliz; per. s angl. 3rd ed., corr. Moscow: Laboratoriya znanij, 2017. 694 p. ISBN 978-5-00101-014-2 (Vol. 1); ISBN 978-5-00101013-5V. URL: http://binom-press.ru/books_1/biology/lenindger_1.pdf (date of access 25.01.2020) (in Russian).

5. Smirnova I. R. Satyukova L. P., Shopinskaya M. I. (2016) Funkcional'nyj keratin pera kak istochnik belka $i$ nezamenimy aminokislot $v$ kormlenii sel'skohozyajstvennoj pticy. Problemy veterinarnoj sanitarii, gigieny i ekologii. № 3. P. 78-83 (in Russian).

6. Usvoenie rasteniyami aminokislot. Agrohimiya. Informacionnyj nekommercheskij resurs. - URL: http://agrohimija.ru/mikroorganizmy-pochvy/1821-usvoenie-rasteniyami-aminokislot.html (date of access: 26.01.2020) (in Russian).

7. Volik V. G., Ismailova D. Yu., Erohina O. N. et al. (2011) Effektivnoe ispol'zovanie vtorichnogo syr'ya, poluchaemogo pri pererabotke pticy. Ptica i pticeprodukty. № 3 . P. 16-19. URL: http://www.vniipp.ru/images/statya/0311/s16.pdf (date of access 29.01.2020) (in Russian).

8. Casarin F., Cladera-Olivera F., Brandelli A. (2008) Use of Poultry Byproduct for Production of Keratinolytic Enzymes. Food and Bioprocess Technology. Vol. 1. P. 301-305. DOI: https://doi.org/10.1007/s11947-008-0091-9.

9. Gupta R., Ramnani P. (2006) Microbial keratinases and their prospective applications: an overview. Applied Microbiology and Biotechnology. Vol. 170. P. 21-33. DOI https://doi.org/10.1007/s00253-005-0239-8.

10. Kirfel J., Magin T. M., Reichelt J. (2003) Keratins: a structural scaffold with emerging functions. Cellular and Molecular Life Sciences CMLS. Vol. 60. P. 56-71. DOI https://doi.org/10.1007/s000180300004.

11. Körner A. (2008) MALDI MS in Analysis of Keratin Fibre Proteins. Applications of Mass Spectrometry in Life Safety. P. 205-212. DOI https://doi.org/10.1007/978-1-4020-8811-7_14.

12. Cao L., Tan H., Liu Y., Xue X., Zhou S. (2008) Characterization of a new keratinolytic Trichoderma atroviride strain F6 that completely degrades native chicken feather. Letters in Applied Microbiology. Vol. 46. P. 389-394. DOI: https://doi.org/10.1111/j.1472-765X.2008.02327.x.

13. Eremeev N. L., Nikolaev I. V., Keruchen'ko I. D. et al. (2009) Enzymatic hydrolysis of keratin-containing stock for obtaining protein hydrolysates. Applied Biochemistry and Microbiology. Vol. 45. No. 6. P. 717-724. DOI: https://doi.org/10.1134/S0003683809060131.

\section{Сведения об авторе}

Брындина Лариса Васильевна - доктор сельскохозяйственных наук, профессор кафедры безопасности жизнедеятельности и правовых отношений ФГБОУ ВО «Воронежский государственный лесотехнический университет имени Г.Ф. Морозова», г. Воронеж, Российская Федерация; e-mail: bryndinv@mail.ru.

\section{Information about the author}

Bryndina Larisa Vasilyevna - DSc (Agriculture), Professor of the Department of Life Safety and Legal Relations, FSBEI HE "Voronezh State University of Forestry and Technologies named after G.F. Morozov", Voronezh, Russian Federation; e-mail: bryndinv@mail.ru. 